This is the post-print version of an article printed at www.springerlink.com. Jones, G. (2013). The Horizontal and Vertical Fragmentation of Academic Work and the Challenge for Academic Governance and Leadership. Pacific Education Review, 14 (1), 75-83. The final publication is available at http://link.springer.com/article/10.1007\%2Fs12564-013-9251-3\#page-1

\title{
The Horizontal and Vertical Fragmentation of Academic Work and the Challenge for Academic Governance and Leadership
}

\author{
Glen A. Jones ${ }^{1}$
}

Academic work has become increasingly fragmented. The horizontal fragmentation of the profession into disciplinary tribes has been accompanied by the increasing role played by student affairs and educational development professionals who are located outside the academic units, but are actively engaged in types of academic work, including supporting teaching and student learning. More recently, there has been an increasing vertical fragmentation of academic work within academic units with the increasing use of contract university teachers and research assistants. In Canada, both horizontal and vertical fragmentation have occurred while universities and strong faculty unions have protected the "traditional" tenure-stream professoriate. Drawing on recent research, the author argues that Canadian full-time faculty have high levels of job satisfaction and are well remunerated, productive scholars. Maintaining the status and supportive working conditions of the full-time, tenure-stream professoriate has largely been accomplished through the labour cost efficiencies created by the increasing use of part-time, contractual university teachers, now frequently represented by labour unions that are quite distinct from their full-time peers. This paper discusses the challenges for academic governance and leadership associated with this increasing fragmentation of academic work in the context of the "global" university.

\section{Introduction:}

\footnotetext{
${ }^{1}$ Glen A. Jones is the Ontario Research Chair in Postsecondary Education Policy and Measurement and Professor of Higher Education at the Ontario Institute for Studies in Education at the University of Toronto.
} 
It is commonly argued that the dramatic changes and reforms to higher education that have taken place over the last few decades have created a crisis for the professoriate. Universities have been repositioned as key contributors to economic development within the context of the knowledge economy, and this shift has had implications for the role of the professoriate as knowledge creators, but it has also repositioned university teachers as knowledge workers in the context of mass higher education systems, with increasing enrolments (and class sizes), managerial practices, and expectations for research productivity (for example, see Altbach, 2000; Cavalli \& Moscati, 2010; Enders \& Musselin, 2008; Finkelstein, 2003; Gould, 2006; Jones, 2006).

The fragmented nature of the academic profession has long been regarded as an important organizational characteristic of the modern university (Baldridge, Curtis, Ecker \& Riley, 1986), but recent reforms appear to be leading towards new forms of fragmentation. In 1963 Burton Clark noted that the strong internal controls of the medical profession meant that the professional standards of this group have a tremendous influence over medical organizations like hospitals. In contrast, the academic profession is, in essence, composed of a multitude of quite different professions where the loyalty of individual professors focuses far more on their discipline or field than on the academic profession as a holistic professional category. With the growth in power of the disciplines within the modern university, and emergence of the multiversity as an organizational form, there was little need for interaction between the department of physics and the department of English beyond the need for members of both units to sit on university-wide committees. English professors assumed the primary responsibility for determining the curriculum of their courses and programs, and peer-review mechanisms within the discipline ensure that the expertise of other professors of English around the world play a far 
greater role in decisions about publication and professional status, including tenure and promotion, than the expertise of physics professors working in the building across the street. The academic profession is fragmented and there are major differences among the various academic tribes in terms of epistemology, career patterns, and professional standards (Baldridge, Curtis, Ecker \& Riley, 1986; Becher, 1989). More recent research suggests that the influence of the disciplines may be weakening, and that there may be reasons to rethink the "academic tribes and territories metaphor," but the disciplines continue to represent a powerful force in academic life and the fragmentation of the academic profession continues (Trowler, Saunders \& Bamber, 2012).

While the academic profession has long been fragmented along disciplinary lines of expertise, and, in response to the growth of knowledge, is increasingly fragmented according to sub-disciplinary and sub-sub-disciplinary areas of expertise, more recent changes appear to be creating different categories of workers within these disciplinary clusters. In many systems reforms have led to changes in the employment of university teachers, including the increasing use of part-time or non-permanent faculty who have quite different conditions of employment than their traditional full-time peers working under more permanent or tenured appointments (Cavalli \& Moscati, 2010; Macfarlane, 2011).

While variations on these changes are taking place in many jurisdictions, there are clearly national nuances. Professors are employed within quite different national systems of higher education, operating under different labour laws, funding arrangements, and historical 
traditions $^{2}$. My objective in this paper is to review a number of recent studies focusing on the professoriate within the context of Canadian universities and discuss the implications of these findings for leadership and university governance. What are the key lessons from recent research on Canadian university professors, and what are the implications for university leadership, especially at the level of the department or faculty, and institutional governance? I will conclude by suggesting a program of further research on academic work in Canada and comparative studies of the fragmentation, and related career tracks and pathways, of academic work in different countries.

\section{Historical Foundations:}

Like other systems, it is quite possible to trace the roots of Canadian higher education to the emergence of the medieval university in Europe, but in reality many of the key elements of Canadian university governance, administration, and the conditions of academic work only became concretized in the 1960s and 1970s (Jones, 1996). Prior to World War II Canadian higher education was composed of a handful of publicly supported provincial universities receiving quite modest government grants and a larger number of small, private, denominational institutions. Canada's transition from elite to mass higher education began in earnest following the war, and many of the key elements of the current arrangements emerged as a function of the dramatic expansion and transformation of the provincial higher education systems in the 1960s and early 1970s (Jones, 1996). Two of these changes, the reform of university governance and faculty unionization, are particularly relevant to this discussion.

\footnotetext{
${ }^{2}$ For a thoughtful analysis of these differences in the case of France, Germany and the United States, see Musselin, 2010.
} 
The governance structure of Canadian universities became the subject of considerable debate throughout the 1960s (Jones, 1996). Most Canadian universities had adopted a bicameral governance structure loosely following a model that had emerged following the Flavelle Commission review of the University of Toronto in 1906. Almost all Canadian universities had been created as private, not-for-profit corporations and each institution had a unique university Act approved by the provincial legislature that established both a governing board and an academic senate (Jones, 2001). The governing board was generally assigned oversight responsibility for the administration and finance of the university, including the appointment of the president ${ }^{3}$. The governing board was largely composed of external members appointed by the government, alumni, or, in a small number of cases, by the board itself. The senate was assigned authority over the academic policies of the university, including the approval of admission requirements, programs, curriculum, and grading practices, and these bodies were largely composed of internal members, especially academic administrators and senior faculty (Jones, 1996).

Demands for greater representation from internal constituencies in the membership of both boards and senates led almost every Canadian university to revise its governance structure in the late 1960s or early 1970s. The membership of the governing board at most universities was expanded to include both faculty and students, and the membership of senates was expanded to include student participation. The same principles of community participation were extended to other levels of decision-making, with student, faculty and, frequently, administrative staff representation on department and faculty councils, and in the composition of advisory groups

\footnotetext{
${ }^{3}$ While the president is appointed by the board at most Canadian universities, there are a number of Frenchlanguage universities in Quebec where the rector is elected.
} 
and search committees for senior university administrative appointments, including the president (Jones, 2002).

University professors were employees of the university, and the terms and conditions of their employment varied by institution. In the early 1970s, when provincial governments moved to control expenditures in the face of declining revenues and a major recession, faculty at some institutions became concerned with issues of job security and remuneration and pushed for their university faculty association to be recognized as a labour union under provincial labour law. With support from the Canadian Association for University Teachers, a national umbrella organization representing institutional faculty associations, the majority of full-time Canadian university faculty were members of recognized unions by the 1980s (Tudivor, 1999).

The importance of unionization in terms of understanding the context of academic work in Canada is difficult to overstate. Unionized faculty associations clearly played a role in representing the interests of professors in negotiating with university management on salaries and benefits, but they also quickly moved to imbed policies on key issues related to academic work in collective agreements, including policies on faculty appointments, tenure and promotion. Tenure policies existed at some Canadian universities long before unionization, but collective bargaining served to limit administrative discretion over tenure, concretized detailed procedures for the process of review, and established criteria for tenure decisions (Horn, 1999). Collective bargaining also defined tenure, essentially ensuring that tenured faculty held permanent appointments and could only be dismissed for clear cause ${ }^{4}$. Tenure quickly became an elaborate

\footnotetext{
${ }^{4}$ But not just any cause, the circumstances leading to dismissal have to involve quite extreme forms of misconduct approaching or including criminal activity.
} 
process involving evidence of a candidate's research, teaching and service activities, the collection of external assessments of research and sometimes teaching, and multiple levels of review and oversight (Gravestock, Greenleaf \& Jones, 2009). The impact was not limited to unionized faculty. At most other universities, faculty associations entered into formal agreements with the university that established similar tenure, promotion and appointment policies that cannot be modified without the agreement of both the association and the university.

Collective agreements also define the bargaining unit, essentially determining who is a member of the union and who is not. At most universities the faculty union includes all full-time, tenure stream faculty and, not infrequently, librarians. In some cases the same union represents full-time faculty who do not hold tenure-stream positions, or, in a more limited number of institutions, a parallel category of appointment that emphasizes teaching. The collective agreement also defines the line between academic peers and university management. In all cases department heads or chairs are defined as members of the bargaining unit, and the mechanism for appointing or electing these positions is enshrined in the agreement. Deans of faculties are excluded from the bargaining unit, and positioned as university management. To some extent the agreement also defines the roles of both chairs and deans in key faculty decisions by specifying their roles, responsibilities, and discretion within appointment, tenure and promotion policies (Boyko \& Jones, 2010).

The reform of university governance and the rise of unionization in the 1960s and the 1970s led to key changes in the Canadian university context, including the development of participatory governance structures where faculty and students were members of boards and senates, and collective bargaining which defined "traditional" faculty appointments and faculty 
work, through tenure and promotion policies. I will return to these points after briefly reviewing some findings from recent research on the professoriate in Canada.

\section{The Academic Profession in Canada: Recent Research}

There has been surprisingly little research on Canadian university faculty, and, until quite recently, there has been little comparative analysis of the Canadian situation in relation to other developed western nations. However, in the last few years several projects have been helpful in contributing to our basic understanding of the state of university faculty in Canada.

The Changing Academic Profession (CAP) project involved the administration of a common survey instrument to a sample of university faculty in 18 countries. The questionnaire focused on faculty demographics, job satisfaction, workload, and perceptions on a range of issues, including facilities, resources, governance, and university management. The Canadian component of the study, which focused on full-time faculty, was conducted in 2007-2008; over 1100 responses were received from faculty employed at 18 Canadian universities 5 .

The picture of the Canadian professoriate that emerged from the CAP study is not one of an occupational group in crisis. Respondents indicated quite high levels of overall job satisfaction with the vast majority indicating that they were quite pleased with their academic careers (Weinrib, Jones, Metcalf, Fisher, Gingras, Rubenson, \& Snee, in press). Most faculty indicated that they would make the same career choice again.

\footnotetext{
${ }^{5}$ The Canadian research team was led by Amy Metcalfe and included Donald Fisher, Yves Gingras, Glen A. Jones, Kjell Rubenson, and Iain Snee. Additional information on the methodology employed in the Canadian component can be found in Metcalfe, Fisher, Rubenson, Snee, Gingras, \& Jones, 2011.
} 
Generally speaking, most respondents also indicated that they were quite satisfied with their overall working conditions. With the exception of some research facilities, most faculty indicated that they were satisfied with the physical infrastructure associated with their working environment and with other types of institutional support (Weinrib et al, in press). They believe that they had the ability to influence decisions at the local (department) level, though, not surprisingly, their perceived level of influence decreased at the faculty and institutional levels of authority (Metcalfe, Fisher, Rubenson, Snee, Gingras, \& Jones, 2011).

The story that emerged from this study of full-time faculty is not entirely positive. Respondents were far less positive when looking forward; they were concerned with the future of the academic profession in Canada (Weinrib et al, in press). There were also important differences in faculty response by rank and level of remuneration. Full professors with higher salaries reported somewhat higher levels of job satisfaction than faculty at lower ranks with lower salaries, though there were only modest differences in responses to most questions in the study between junior (assistant) professors and their more senior colleagues (associate and full professors) (Jones, Weinrib, et al 2012). Many faculty were concerned with institutional management; they found central administrative processes cumbersome and frustrating (Weinrib et al, in press). Many faculty were also concerned with the level of research funding. There were also some important differences in response by gender, with female faculty reporting lower levels of job satisfaction and higher levels of personal stress associated with their work than their male counterparts, a finding that reconfirms previous research on gender inequities within the academic profession in Canada (see, for example, Acker, 2003; Acker \& Armenti, 2004).

However, the overall findings of the study suggest that Canadian university faculty are doing reasonably well. Almost three-quarters of respondents indicated that they were satisfied or 
very satisfied with their work situation (and less than $10 \%$ indicated low or very low levels of satisfaction), a response suggesting that Canadian academics have higher levels of job satisfaction than their peers in, for example, the United States, the United Kingdom or Australia.

The conclusion that full-time faculty are doing reasonably well has also been supported by several recent comparative studies focusing on faculty remuneration. Rumbly, Pacheco \& Altbach (2008) compared national salary data for professors in public universities from 15 countries and found that Canadian university faculty salaries compared quite favourably with most of the other jurisdictions included in their analysis. Of the 15 countries included in their study, Canada ranked second (following Saudi Arabia) for salaries at both the senior (full professor) and junior (assistant professor) faculty levels. A more detailed analysis of faculty remuneration was obtained in a recent follow-up study involving the comparative analysis salary data from 28 countries (Altbach, Yudkevich, Reisberg, Pacheco \& Androushchak, 2012). The salaries of Canadian full-time faculty were the highest compared with all of the other countries included in the study. (Jones \& Weinrib, 2012).

Given these findings, it is possible to conclude that the narrative of crisis which seems to run through most of the international literature on higher education does not accurately capture the Canadian situation (Metcalfe, Fisher, Rubenson, Snee, Gingras, \& Jones, 2011). While there are certainly concerns about the future, and important differences in perception by rank and gender, most full-time faculty are reasonably satisfied with the current state of the academic profession in Canada. The self-reported data from the CAP study suggests that Canadian university faculty are hard-working, productive scholars who have the institutional resources necessary to do their work. 
It is also important to note that in addition to positive faculty perceptions of job satisfaction, national data clearly indicates that the number of full-time faculty employed by Canadian universities is growing. Unlike some other countries, the number of full-time faculty in has been steadily increasing, rising from 30,399 in 2000-2001 to 38,904 in 2008-2009 (CAUT, 2011). Obtaining parallel data specific to tenured and tenure-stream data is more challenging given the way these data are collected and reported, but the available data clearly suggests that the number of faculty in the tenure-stream category has increased during this same time period.

Why are full-time faculty doing so well given the increasing narrative of decline that ruminates through much of the literature on academic work (for example, see Altbach, 2000)? I believe that there are two complementary reasons why Canadian university faculty have been protected: 1) unionization; and 2) institutional responses to pressures for increased participation in higher education and increasing university research activity, both associated with government attempts to reposition higher education in relation to the knowledge economy.

Faculty unionization has played an important role in protecting Canadian university professors. Collective bargaining has protected faculty salaries and working conditions, as well as limited administrative discretion over important academic issues related to the evaluation of faculty performance, the criteria and determination of tenure, and appointment and promotion procedures (Horn, 1999; for tenure see Gravestock, Greenleaf and Jones, 2009). At the same time, collective bargaining has defined the bargaining unit, frequently placing full-time faculty under the protection of an influential institution-based union, while placing other employees, such as part-time instructors or those whose academic work is otherwise defined, outside the protection of the faculty union. 
Faculty unionization has protected the faculty that are "inside" the union, but it has also contributed to the structural fragmentation of academic work. Since those "outside" the faculty union see that they are frequently teaching the same courses or pursuing the same research activities as those inside but with very different levels of remuneration and benefits, they have quite naturally sought ways of improving their working conditions and the level of job security. Unions representing other categories of academic workers have emerged on many university campuses, and while these arrangements are frequently complex and idiosyncratic by university, it is not uncommon to have separate bargaining units representing part-time contract instructors, teaching assistants (frequently graduate students teaching undergraduate courses), and research assistants (who support research activities). In addition, there may be separate arrangements for specialized technical staff supporting the research enterprise (such as technical staff supporting specialized laboratory facilities) or the learning enterprise (such as student affairs professionals, counselors, and student advisors). As Dobbie and Robinson (2008) have noted, higher education may be the most unionized sector within Canadian society, and the movement towards the unionization of contingent university faculty and other "academic workers" is a natural evolution within this context.

Macfarlane has referred to the increasing emergence of workers who are associated with components of academic work, such as teaching, without responsibility for the other components, such as research and service, as the "rise of the para-academic" (2011, p. 59), and there are certainly many examples of this transition in Canada. However, Macfarlane views this change as a component of the broader "morphing of academic practice" where the holistic concept of academic work is "unbundled." He argues that "all-around" professors who are responsible for all three major categories of academic work (teaching, research, and service) are 
disappearing and being replaced by para-academics with more specialized roles. The situation in Canada seems to be quite different than the jurisdictions that Macfarlane is including in his analysis, since while there are larger numbers of individuals who might be categorized as paraacademics, increasingly represented by organized labour groups that define and protect the boundaries of these worker categories, these changes are taking place at the same time as universities and unions have protected "all-around" academics (in Canada the full-time, tenurestream). As already noted, collective agreements have protected definitions of academic work that include teaching, research and service, and the findings of the CAP survey confirm that the vast majority of full-time faculty respondents were, in-fact, performing these three functions.

It is also important to note a key difference between "para-academics" working within the university environment and para-professionals working in other fields, such as medicine, engineering and law. In other professions the hierarchical arrangements that differentiate the professional from the para-professional are largely defined by education, the specialized preparation to become a para-professional rather than a professional, and licensure. Generally speaking, these differences do not exist in the university environment where contingent university teachers frequently have the same education background as tenure-stream professors. In other words, para-academics are not lesser professionals in the higher education context, but are frequently fully trained professionals who work within a different employment category, with different definitions and conditions of work.

While unionization has played a large role in protecting the working conditions of university faculty, all collective bargaining involves two parties, and the universities have clearly supported the protection of the tenure-stream professoriate. Like other countries, Canada's federal and provincial governments have positioned universities as key institutions in the context 
of the knowledge economy and there has been an expansion of support for knowledge creation and innovation while at the same time encouraging increasing participation in postsecondary education. There is increasing competition for research and infrastructure support, and it has been in the best interests of institutions to maintain a strong tenure-stream professoriate in order to grow its research portfolio (which, in turn, leverages other resources, not to mention prestige), but also to be successful in an increasingly competitive national and international labour market. However, in order to protect a category of "all-around" faculty, universities have increasingly turned to new job categories of academic worker, with quite different levels of remuneration and benefit arrangements, in order to balance the budget.

The growth in full-time faculty and student enrolment since 2000 is presented in Figure 1. While the number of full-time faculty have increased by approximately $25 \%$ since 2000 (the base year used in this analysis), the growth in full-time faculty positions has not kept pace with the increase in full-time and total student enrolment. The different pace of growth in faculty and students explains the need to hire contract (non-tenure-stream) university teachers to meet student demands for courses, as well as increases in class size.

Figure 1: Percentage increase in full-time faculty, full-student students, and total students (headcount) in Canadian universities from 2000 to 2008 


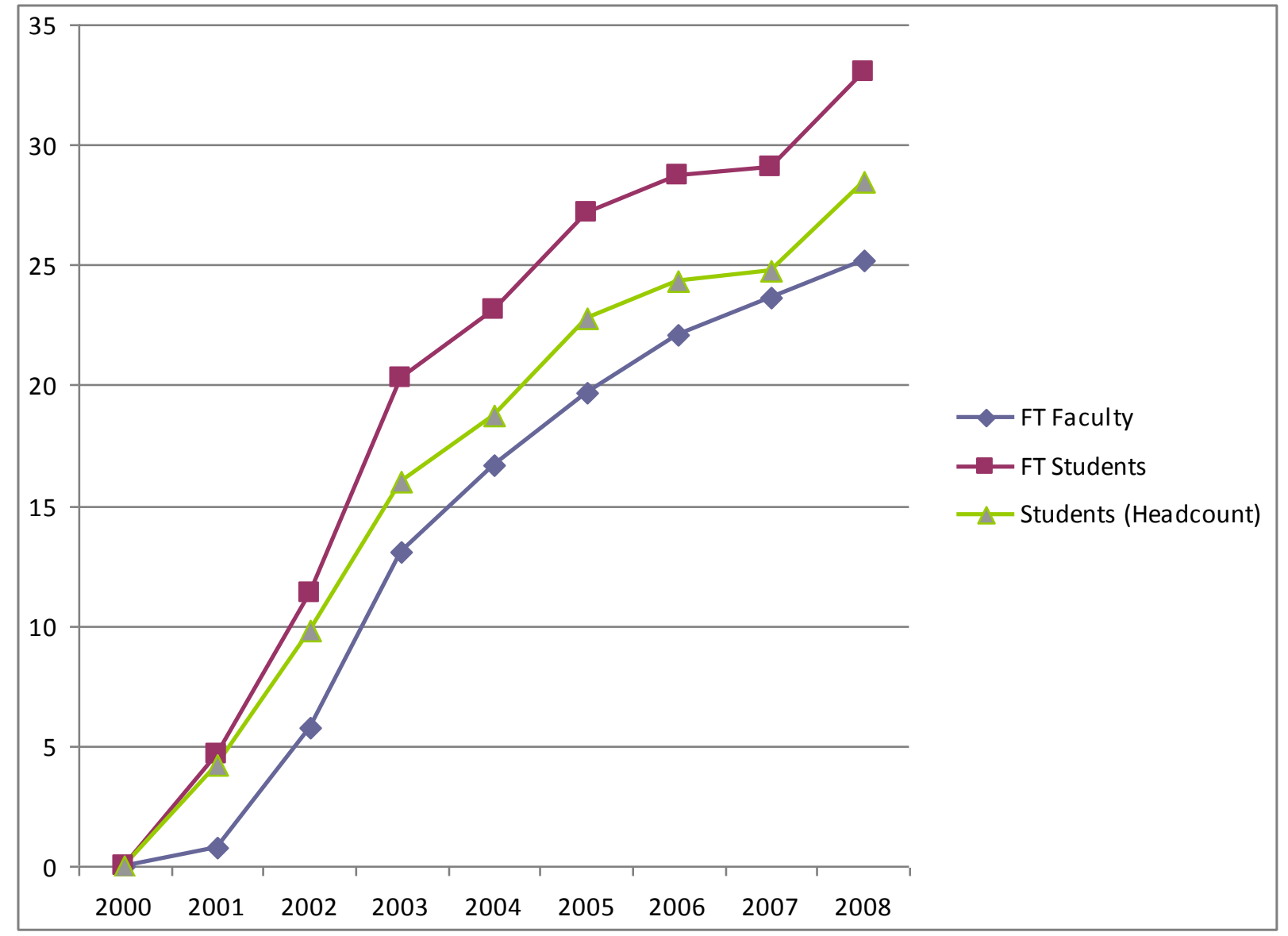

Source: Statistics Canada derived from various years of the CAUT Almanac.

The relatively positive picture of tenure-stream faculty that emerges from the CAP and other recent studies does not mean that their situation in Canada is in any sense utopic; there are concerns about increasing levels of stress, class-size, workload, research funding and a range of issues related to working conditions and the future of the academic profession. However, recent studies suggest that the traditional "all-around" professoriate in Canada is not in crisis, but that protecting this full-time, tenure-stream category of worker has meant increasing the number and categories of what Macfarlane refers to as "quasi-academics," workers who are, in turn, seeking greater benefits and security through unionization and the protection of new categories of 
academic workers. In the next section I will discuss some of the important implications of these changes for Canadian university governance and leadership.

\section{Challenges for Governance and Leadership:}

As noted above, the structure of university governance in Canada was reformed in the late 1960s and early 1970s with almost all institutions revising their charter legislation to increase the participation of internal constituencies, especially students, faculty, and to a lesser extent administrative staff, on formal governing bodies including both governing boards and academic senates. The general assumption was that internal constituencies should play an important role in institutional decision-making at all levels. Defining the constituency of faculty was relatively easy during this time period; university faculty were full-time, permanent employees, and while universities hired part-time instructors, these positions were usually created to fill short-term gaps while the institution searched for a full-time appointment, or to provide an opportunity for students to learn from working professionals who would moonlight as university teachers. The tenure-stream category was the default position.

The fragmentation of academic work raises serious questions concerning the representation of academic interests within university governance. If there are multiple categories of academic workers who are in some respects performing similar and overlapping work, who should represent the interests of the academy within institutional self-governance?

The answer from at least some unions representing the "traditional" professoriate is that while they recognize the important role played by part-time, contract instructors in the work of the university, the academic interests of the institution are best represented by "all-around" faculty, to 
return to Macfarlane's term, who are engaged in research, teaching and service. The permanent and multi-dimensional nature of these positions means that "traditional" faculty should continue to play the central role in the decision-making processes of the university. Maintaining this role becomes another way of protecting the special nature of the tenure-stream and, by definition, using the same boundaries that define different categories of academic workers to retain the powerful privileges assigned to the full-time professoriate within university governance.

In some universities unions representing part-time faculty have successfully fought for the representation of their members on boards and senates. The central argument is that part-time faculty are no longer simply marginalized, itinerant workers in the fields of academe. These instructors frequently have doctoral degrees and engage in research activities. Some of these instructors may have been teaching at the same university for many years and have heavier teaching loads than their tenure-stream peers (see Rajagopal, 2001). There is little doubt that the influence of part-time or contract faculty as a category of worker has been increasing at many universities; strikes by part-time instructors and teaching assistants have, in several instances, essentially shutdown universities ${ }^{6}$.

The issue is not limited to contract teaching faculty. Similar arguments can be raised given the increasingly important role assigned to student affairs professionals, educational developers, specialists in academic computing, and research assistants. As academic work becomes increasingly fragmented, Canadian universities will need to fully consider defining or redefining the "self" in self-governing, and these decisions will have important implications for academic workers,

\footnotetext{
${ }^{6}$ The strike at York University in 2008/2009 is a good example. The Canadian Union of Public Employees Local 3903, representing the interests of 3000 contract faculty, teaching assistants and research assistants, went on strike in November of 2008. The University cancelled almost all courses during this 85 day labour dispute. The strike ended when the Government of Ontario passed legislation forcing employees back to work.
} 
regardless of their category. These issues become particularly important in the Canadian context where universities have generally protected, rather than deskilled or demised, the "all-together" professoriate, but they have done so by increasingly relying on contract workers with very different conditions of employment. The governance challenges associated with the fragmentation of academic work will only increase if one assumes that universities will continue to be challenged by their financial circumstances.

Collective bargaining and the fragmentation of academic work raises somewhat similar challenges for academic leaders, especially at the level of the department chair and dean. As already noted, the collective agreements for full-time faculty assist in defining the roles of chairs and deans, particularly in relation to academic personnel decisions such as appointments, tenure and promotion. The assumption within these agreements is that department chairs/heads are members of the bargaining unit; they are the first among equals within what are assumed to be the collegial decision-making processes of the department (Boyko \& Jones, 2010).

The department head may be first among equals within the "traditional" professoriate, but this individual is clearly management from the perspectives of other quasi-academic worker categories. Subject to the provisions of collective agreements, decisions on teaching assignments, for example, are made locally at the department level and the department head becomes the frontline representative of the university as employer. The fragmentation of academic work and the related categorization of academic workers into distinct employee groups serves to create hierarchical authority relationships between groups. Unionization positions the department head as a peer among the tenure-stream professoriate, and as a manager over contract faculty, and dealing with these quite different relationships represent a relatively new challenge for academic leaders. As academic work becomes increasingly fragmented, with, for example, separate collective agreements 
covering the work of contract instructors, teaching assistants and research assistants, the role of the department chair becomes increasingly complex, in part because of the technical complexity of working with different union arrangements, but also because of the challenges of navigating pathways between the "us" and "them" of different groups of academic workers.

Another way of looking at this shift is to recognize that the disciplinary fragmentation of academic work was largely horizontal, and while one might argue that there are increasing differences in status associated with disciplines that are regarded as closer to the market or receive preferential research funding compared to others, the essential organizational arrangement is relatively flat and composed of clusters of academic workers divided by research and teaching foci. More recent changes have introduced new forms of both horizontal and vertical fragmentation. New forms of horizontal fragmentation are associated with the growth of quasi-academics beyond the borders of the academic unit, such as educational developers, curriculum counsellors, and student affairs professionals. Organizational units engaged in types of teaching and research functions now play important roles within the university, in parallel with the more traditional academic units where "all-around" faculty reside. Vertical fragmentation occurs with the emergence of different categories of academic workers within the traditional academic units where these new categories are clearly hierarchically differentiated from the "traditional" full-time faculty. This differentiation may have nothing to do with the quality of activity or performance of these workers; but the ways in which these workers are defined effectively positions full-time faculty as components of a comparatively well-paid management class (who determine the curriculum, the assignment of teaching responsibilities, and select or recommend the leader of the local academic unit) and other workers in positions with lower salaries and benefits, and far less authority and influence over the local decisions that are central to academic work. 


\section{A New Research Agenda}

While recent studies have provided us with a clearer picture of some aspects of the academic profession in Canada, there is a tremendous need for further research. The Canadian data infrastructure related to higher education collects relatively little data on the academic profession in Canada. In 2012 Statistics Canada decided to eliminate the collection of data on full-time university faculty, and so even the very basic level data on full-time faculty members by type of appointment, gender, age, and area of study will no longer be available. Most importantly in the context of this paper, there are no national data available on part-time faculty, and most of what we know about these other categories of academic workers emerged from important scholarly studies conducted in the 1990s (Rajagopaul, 2002). In order to understand the academic profession in Canada there is a need for a more robust national data infrastructure that is expanded to collect and analyze data on part-time faculty working at Canadian universities as well as additional data on full-time faculty.

It is also extremely important to understand how these complex intersections between worker categories are understood and operationalized at the level of the local academic unit. Detailed case studies of academic departments at Canadian research universities would help us understand how decisions about the allocation of workload between groups are made and interpreted. Case studies of local units would help us understand the degree and types of horizontal and vertical fragmentation that are occurring and what this means for the academic profession. Given the increasing importance placed on academic research, these studies would also help us understand the implications of major research awards, such as research chairs, on the academic work and life of the department, and the implications of large-scale research funding on the relationships between academic workers. 
At the same time, this paper illustrates that there may be important differences in the organization of, and career patterns associated with, "traditional" faculty in different countries. The discourse of demise of the "traditional" professoriate which has been a theme in recent literature on academic work does not capture the Canadian situation, in part because of structural factors, such as unionization, that have protected Canadian university faculty from certain types of reforms. There is a need to understand and compare the ways in which academic work is constructed by higher education systems in different jurisdictions in order to understand differences in how academic work is defined, the pathways of traditional academic careers, and differences in the ways academic work is supported (or not) by institutional, system, and/or national policies (through sabbaticals, research grants, maternity/parental leaves, housing allowances, etc.). Our failure to understand these important differences severely limits our ability to understand some of the important factors that may underscore trends in academic mobility, worker satisfaction, and research and teaching productivity.

Acknowledgement: An earlier version of this paper was presented at the World Universities Networks' "Ideas and Universities" conference entitled The Changing Roles of Academics and Administrators in Times of Uncertainty hosted by the Hong Kong Institute for Education, Hong Kong, November 3-4, 2011. I am extremely grateful to Ka Ho Mok for his leadership in organizing this event and for the comments that I received from conference participants. A number of the ideas presented in this paper emerged from my discussions with Julian Weinrib and Martin Finkelstein.

\section{References:}

Acker, S. (2003) The concerns of Canadian women academics: Will faculty shortages make things better or worse? McGill Journal of Education 38 (3): 391-405.

Acker, S., \& Armenti, C. (2004) Sleepless in academia. Gender and Education 16 (1): 3-24. 
Altbach, P. G. (2000). The Deterioration of the Academic Estate: International Patterns of Academic Work. In The Changing Academic Workplace: Comparative Perspectives (Chesnut Hill, MA; Boston College Center for International Higher Education).

Altbach, P., Yudkevich, M., Reisberg, L., Pacheco, I. \& Androushchak, A. (Eds.). (in press). Paying the professoriate: A Global Comparison of Compensation and Contracts. New York: Routledge.

Baldridge, J. V., Curtis, D. V., Ecker, G. P., \& Riley, G. L. (1986). Alternative Models of Governance in Higher Education, In Marvin W. Peterson (Ed.), ASHE Reader on Organization_and Governance in Higher Education, third edition (pp. 22-27). Lexington: Ginn Press.

Becher, T. (1989). Academic tribes and territories: Intellectual enquiry and the cultures of disciplines. Milton Keynes, U.K.: The Society for Research into Higher Education and Open University Press.

Boyko, L. (2009). An Examination of Academic Department Chairs in Canadian Universities. Unpublished Ph.D. Thesis, University of Toronto.

Boyko, L. \& Jones, G. A. (2010). The roles and responsibilities of middle management (Chairs and Deans) in Canadian universities. In V. L. Meek, L. Goedegebuure, R. Santiago, and T. Carvalho (Eds.). The Changing Dynamics of Higher Education Middle Management. Dordrecht, The Netherlands: Springer (pp. 83-102).

CAUT (2011). CAUT almanac of post-secondary education. Ottawa: Canadian Association of University Teachers.

Cavalli, A., and Moscati, R. (2010). Academic Systems and Professional Conditions in Five European Countries. European Review, 18 Supplement no. 1, S35-S53.

Clark, B. R. (1963). Faculty organization and authority. In Lunsford, T. (ed.), The study of academic administration. Boulder: Western Interstate Commission for Higher Education.

Dobbie, D. \& Robinson, I. (2008). Reorganizing higher education in the United States and Canada: The erosion of tenure and the unionization of contingent faculty. Labour Studies Journal, 33 (1), 117-140.

Enders, J., and Musselin, C. (2008). Back to the Future? The Academic Professions in the $21^{\text {st }}$ Century. In Higher Education to 2030: Volume 1, Demography. Paris; Organization for Economic Cooperation and Development. Pp. 125-150. 
Finkelstein, M. (2003). The Morphing of the American Academic Profession. Liberal Education.Association of American Colleges and Universities, Fall, www.aacu.org/liberaleducation/le-fa03/le-sfa03feature.cfm.

Finkelstein, M. (2010). Diversification in the Academic Workforce: The case of the US and implications for Europe. European Review, 18 (1), S141-S156.

Gould, E. (2006). Professor or knowledge worker? The politics of defining faculty work. Higher Education in Europe, 31 (3), 241-250.

Gravestock, P. (2011). Does Teaching Matter? The Role of Teaching in the Tenure Policies of Canadian Universities. Unpublished Ph.D. Thesis, University of Toronto.

Gravestock, P., Greenleaf, E., \& Jones, G. A. (2009). Defining academic work: An analysis of faculty tenure and promotion policies in Canadian universities. Paper presented at the Annual Meeting of the Canadian Society for the Study of Higher Education, Ottawa, May $25-27$.

Horn, M. (1999). Academic freedom in Canada: A history. Toronto: University of Toronto Press Incorporated.

Jones, G. A. (1996). Governments, Governance, and Canadian Universities. In John C. Smart (Ed.), Higher Education: Handbook of Theory and Research, Volume XI (pp. 337-371). New York, NY: Agathon Press.

Jones, G. A. (2002). The Structure of University Governance in Canada: A Policy Network Approach. In Amaral, Alberto, Jones, Glen A. and Karseth, Berit (Eds.), Governing Higher Education: National Perspectives on Institutional Governance. Dordrecht, The Netherlands: Kluwer Academic Publishers (pp. 213-234).

Jones, G. A. (2006). The restructuring of academic work: Themes and observations. Higher Education in Europe, 31(3) 317-325.

Jones, G. A. (2007). The academic as a work in progress. Academic Matters, April 2007, 10-13.

Jones, G. A. \& Weinrib, J. (2012). The organization of academic work and the remuneration of faculty at Canadian universities. In Phil Altbach, Liz Reisberg, Maria Yukevich, Gregory Androushchak, and Ivan F. Pacheco, Paying the Professoriate: A Global Comparison of Compensation and Contracts (pp. 83-93). New York: Routledge.

Jones, G. A., Weinrib, J., Metcalfe, A. S., Fisher, D., Rubenson, K., \& Snee, I. (2012). Academic work in Canada: Perceptions of early career academics. Higher Education Quarterly, 66 (2), 189-206. 
Locke, W. \& Teichler, U. (Eds.). (2007). The changing conditions for academic work and careers in select countries. Werkstattberichte 66. Kassel, Germany: International Centre for Higher Education Research-Kassel.

Macfarlane, B. (2011). The morphing of academic practice: Unbundling and the rise of the paraacademic. Higher Education Quarterly, 65(1), 59-73.

Metcalfe, A. S. , Fisher, D., Rubenson, K., Snee, I., Gingras, Y., \& Jones, G. A. (2011). Canada: Perspectives on governance and management. In W. Locke, W. K. Cummings, and D. Fisher (Eds.), Governance and management of higher education institutions: Perspectives of the academy (pp. 151-174). Dordrecht: Springer.

Musselin, C. (2010). The market for academics. London: Routledge.

Muzzin, L. (2009). Equity, ethics, academic freedom and the employment of contingent academics. Academic Matters, May 2009, 19-22.

Rajagopal, I. (2002). Hidden academics: Contract faculty in Canadian universities. Toronto, ON: University of Toronto Press.

Rumbly, L., Pacheco, I., \& Altbach, P. (2008). International comparison of academic salaries. Boston: Centre for International Higher Education, Boston College.

Trowler, P., Saunders, M. \& Bamber, V. (Eds.) (2012). Tribes and territories in the $21^{\text {st }}$ century: Rethinking the significance of disciplines in higher education. London: Routledge.

Tudivor, N. (1999). Universities for sale: Resisting corporate control over Canadian higher education. Toronto: James Lorimer and Company.

Weinrib, J., Jones, G. A., Metcalfe, A. S., Fisher, D., Gingras, Y., Rubenson, K., \& Snee, I. (in press). Canada: Canadian university academics' perceptions of job satisfaction - "...the future is not what it used to be." In P. J. Bentley, H. Coates, I. R. Dobson, L. Goedegebuure \& V. L. Meek (Eds.), Job satisfaction around the academic the world. Dordrecht: Springer. 